17. Соломаха Н. Г., Поляков О. К., Суслова О. П. Випробування видів сосен у Донецькому ботанічному саду НАНУ: результати та перспективи. Лісівництво і агролісомеліораиія. Х.: УкрНДІЛГА. 2009. Вип. 116. С. 200-203.

18. Ярмишко В. T. Диагностика повреждений и оценка жизненного состояния деревьев и древостоев в условиях промышленного атмосферного загрязнения. Методы изучения лесных сообществ. Санкт-Петербург: НИИ химии СПбГУ. 2002. С. 154-165.

Надійшла до редколегї 12.07.2016 p.

УДК 202.75:58.006

Б. О. Барановський, В. В. Манюк, І. А. Іванько, Л. О. Кармизова, Д. В. Орищенко

Дніпровський начіональний університет імені Олеся Гончара

\title{
АНАЛІЗ РАРИТЕТНОЇ ФЛОРИ ЛІВОБЕРІЖЖЯ ДОЛИНИ р. ОРІЛЬ
}

Наведено аналіз раритетної фракції флори судинних рослин лівоберіжжя долини р. Оріль лісових екосистем долинно-терасових ландшафтів на території запроектованого національного парку «Орільський». На території лівоберіжжя долини р. Оріль у лісових екосистемах виявлено 1 вид - із Світового червоного списку, 1 вид із Європейського червоного списку, 6 видів - із Червоної книги України, із Червоного списку Дніпропетровської області - 53 види. Доля рідкісних та зникаючих видів лісових екосистем від всієї раритетної флори (140 видів) дослідженої території складає 30 \%, що свідчить про созологічну цінність лісових екосистем долинно-терасових ландшафтів Степової зони України, які, незважаючи на багаторічну антропогенну трансформацію, зберегли достатній рівень фіторізноманіття.

У процесі досліджень флори долини р. Оріль виявлено низку нових місцезнаходжень рідкісних для області та регіону видів.

Ключові слова: аналіз раритетної флори, фіторізноманіття, судинні рослини, екосистеми.

\section{Б. А. Барановский, В. В. Манюк, І. А. Иванько, Л. А. Кармызова, Д. В. Орищенко \\ Днепровский национальній университет имени Олеся Гончара \\ АНАЛИЗ РАРИТЕТНОЙ ФЛОРЫ ЛЕВОБЕРЕЖЬЯ ДОЛИНЫ р. ОРЕЛЬ}

Приведен анализ раритетной фракции флоры сосудистых растений левобережья долины р. Орели лесных экосистем долинно-террасных ландшафтов на территории запроектированного национального парка «Орельский». На территории левобережья долины р. Орели в лесных экосистемах обнаружены 1 вид - из Мирового красного списка, 1 вид из Европейского красного списка, 6 видов из Красной книги Украины, из Красного списка Днепропетровской области - 53 вида. Доля редких и исчезающих видов лесных экосистем от всей раритетной флоры (140 видов) исследованной территории составляет 30 \%, что свидетельствует о созологической ценности лесных экосистем долинно-террасных ландшафтов Степной зоны Украины, которые, несмотря на многолетнюю антропогенную трансформацию, сохранили достаточный уровень фиторазнообразия. В процессе исследований флоры долины р. Орели обнаружен ряд новых местонахождений редких для области и региона видов.

Ключевые слова: анализ раритетной флоры, сосудистые растения, фиторазнообразие, экосистемы.

(C) Б. О. Барановський, В. В. Манюк, І. А. Іванько, Л. О. Кармизова, Д. В. Орищенко, 2017 
B. O. Baranovsky, V. V.Manyuk, I. A. Ivanko, L. O. Karmyzova, D. V. Oryshchenko Oles Honchar Dnipro National University

\section{RARE FLORA ANALYSIS OF THE LEFT ORIL RIVER BANK}

In the work, analysis of rare flora fraction of vascular plants in forest ecosystems on valley-terraced Orel river left bank on the territory of designed Orilsky National Park was performed. In the forest ecosystems, it was identified 1 species listed in the IUCN Red List, 1 species scheduled in the European Red List, and 6 species included in the Red Data Book of Ukraine; 53 specieswere sceduled in the Red List of Dnipropetrovsk Oblast.

Within the investigated area, chare of rare and endangered species in forest ecosystems in relation to the total rare flora (140 species) was $30 \%$; the chare indicates high sozological value of these forest ecosystems on valley-terraced landscapes of Orel river valley in Steppe zone of Ukraine, which still maintaine a sufficient phytodiversity level despite long-term anthropogenic transformation.

In the process of flora survey within the valley of the Orel River, some new flora locations rare for the region were found.

Keywords: analysis of rare flora, vascular plants, phytodiversity, ecosystems.

Як відомо, долинно-терасові ландшафти та окремих їх елементи [15] у порівнянні $з$ іншими територіями відрізняються більш значним біорізноманіттям, i тому числі - різноманіттям раритетної флори. До таких ландшафтів належить $\mathrm{i}$ долина р. Оріль [1].

Серед усіх типів наземних екосистем найціннішими для території Степової зони є лісові екосистеми. Вони є особливо цінним типом рослинності і для об’єктів природно-заповідного фонду Степу України.

Флора та рослинність лісів долини ріки Орілі ще з 30 років XX сторіччя вивчалася О. Л. Бельгардом и Т. Ф. Кириченко [3]. До більш пізніх досліджень належать роботи Ю. Г. Гамули [6; 7] та В. В. Манюка [8; 9]. Узагальнений біоекологічний аналіз флори долини р. Оріль представлено у монографії Б. О. Барановського, В. В. Манюка, І. А. Іванько, Л. О. Кармизової «Аналіз флори національного парку Орільський» [1].

На території Степової зони України, згідно з типологією О. Л. Бельгарда [2], ліси поділяються на заплавні (діброви, вербняки та осокорники), аренні (соснові бори) та байрачні (діброви). У короткозаплавних умовах Степу України, на відміну від довгозплавних, мають місце лише діброви.

В долині р. Оріль у межах Дніпропетровської області деревно-чагарникова рослинність переважно представлена угрупованнями формацій дуба звичайного (Querceta roburi) та сосни звичайної (Pineta sylvestris). Здебільшого ліси з дуба звичайного (Quercus robur L.), які мають природне походження, локалізовані у заплавних місцезростаннях та належать, за типологією природних лісів Степової зони України О. Л. Бельгарда, до короткозаплавних дібров. Природних лісів із сосни звичайної (Pinus sylvestris L.) у долині Орілі не залишилось. Соснові фітоценози представлені виключно штучними культурами різних вікових стадій, станів, ступенів натуралізації, які сформовані в межах надзаплавної тераси та належать до позазаплавних типів лісу.

Матеріали та методи досліджень. Дослідження раритетної фракції флори проводилися за загальноприйнятими методами вивчення флори судинних рослин [5; 10]. Латинські назви видів подано згідно з прийнятою в Україні номенклатурою [14]. Категорії рідкісності видів подано згідно з прийнятими у Світовому, Свропейському та регіональному списках [13] та Червоній книзі України [12]. Дослідження проводилися на лівобережжі долини р. Оріль у Дніпропетровської області в різних лісових екосистемах долинно-терасових ландшафтів на території запроектованого національного парку «Орільський».

Результати та їх обговорення. На території лівобережжя долини р. Оріль у лісових екосистемах виявлено 1 вид - із Світового червоного списку $(\mathrm{R}-3, \mathrm{~V}-1)$, 
1 вид із Свропейського червоного списку $(\mathrm{R}-2, \mathrm{I}-3), 6$ - із Червоної книги України, 3 яких до категорії «неоцінений» належать 2 види, до категорії «рідкісний» 1, до категорії «вразливий» - 3 (табл. 1).

Раритетна фракція флори лісових екосистем складається із 5 відділів, 5 класів та 31 родин та представлена 53 видами. Всі вони належать до Червонного списку Дніпропетровської області. 3 них до категорії «зникаючий» (1) відносять 13 видів, до категорії «вразливий» (2) - 10, до категорії «рідкісний» (3) - 25, до категорії «невизначений» (4) - 5 види судинних рослин.

Доля рідкісних та зникаючих видів лісових екосистем від усієї раритетної флори (140 видів) дослідженої території [1] складає 30 \%, що свідчить про созологічну цінність лісових екосистем долинно-терасових ландшафтів Степової зони України, які, незважаючи на багаторічну антропогенну трансформацію, зберегли достатній рівень фіторізноманіття.

У процесі досліджень флори долини р. Оріль виявлено низку нових місцезнаходжень рідкісних для області та регіону видів.

У районі с. Краснопілля (Магдалинівський р-н) серед фрагментів заплавних дібров Орілі знайдено численну популяцію ластовеня руського (Vincetoxicum rossicum (Kleopov) Barb.) (Барановський, 2015!) - виду із Світового червоного списку. До цієї знахідки були відомі лише два місцезнаходження цього виду на Дніпропетровщині - із заплавних біотопів пригирлової частини р. Кільчень (Барановський, 1995!) та р. Самара біля м. Новомосковська (Рублевська, 2007!).

У районі с. Йосипівка (Магдалинівський р-н) знайдено невеличку популяцію жовтцю багатолистого (Ranunculus polyphyllus Waldst. et Kit. ex Willd.) (Барановський, 2015!), який наведений лише для ділянки біля с. Багате (Новомосковський р-н) (Тарасов, 1971!, 1986!).

У заплавних дібровах Орілі виявлено декілька місцезнаходжень коручки морозниковидної (Epipactis helleborine (L.) Crantz): навпроти с. Семенівка (Новомосковський р-н) (Манюк, 2015!), поблизу с. Степанівка та в Шагарівському лісі (Кармизова, 2015!, Барановський, 2015!). До того були відомі всього три сучасні місцезнаходження цього виду на території області, з них два - на Присамар'ї (Тарасов, Сумароков, 1981!, Манюк, 2003!) та одне - на Приоріллі в районі с. Чернетчина (Манюк, 1999!).

Раритетна флора лісів національного природного парку «Орільський»

\begin{tabular}{|c|c|c|c|c|c|c|}
\hline \multirow[b]{2}{*}{ № } & \multicolumn{2}{|c|}{ Систематичне положення та назва виду } & \multicolumn{4}{|c|}{$\begin{array}{l}\text { Статус виду } \\
\text { та категорії }\end{array}$} \\
\hline & українська & латинська & $\underline{v}$ & 光 & $\underset{\mho}{己}$ & 己 \\
\hline & \multicolumn{2}{|c|}{$\begin{array}{l}\text { I. Відділ Плауноподібні-Lycopodiophyta } \\
\text { Клас Плауновидні-Lycopodiopsida }\end{array}$} & & & & \\
\hline & \multicolumn{2}{|c|}{ Родина Плаунові - Lycopodiaceae } & & & & \\
\hline \multirow[t]{3}{*}{1} & Плаун булавовидний & Lycopodium clavatum L. & 1 & - & - & - \\
\hline & \multicolumn{2}{|c|}{$\begin{array}{l}\text { II. Відділ Хвощеподібні-Equisetophyta } \\
\text { Клас Хвощевидні-Equisetopsida }\end{array}$} & & & & \\
\hline & \multicolumn{2}{|c|}{ Родина Хвощові - Equisetaceae } & & & & \\
\hline \multirow[t]{3}{*}{2} & Хвощ зимуючий & Equisetum hyemale L. & 3 & - & - & - \\
\hline & \multicolumn{2}{|c|}{$\begin{array}{l}\text { III. Відділ Папоротеподібні-Polypodiophyta } \\
\text { Клас Папоротевидні-Polypodiopsida }\end{array}$} & & & & \\
\hline & \multicolumn{2}{|c|}{ Родина Безщитникові - Athyriaceae } & & & & \\
\hline 3 & Безщитник жіночий & Athyrium filix-femina (L.) Roth. & 2 & - & - & - \\
\hline \multirow[t]{2}{*}{4} & Пухирник ламкий & Cystopteris fragilis (L.) Bernh. & 2 & - & - & - \\
\hline & \multicolumn{2}{|c|}{ Родина Невиразнолускові - Dennstaedtiaceae } & & & & \\
\hline
\end{tabular}


Продовження табл. 1

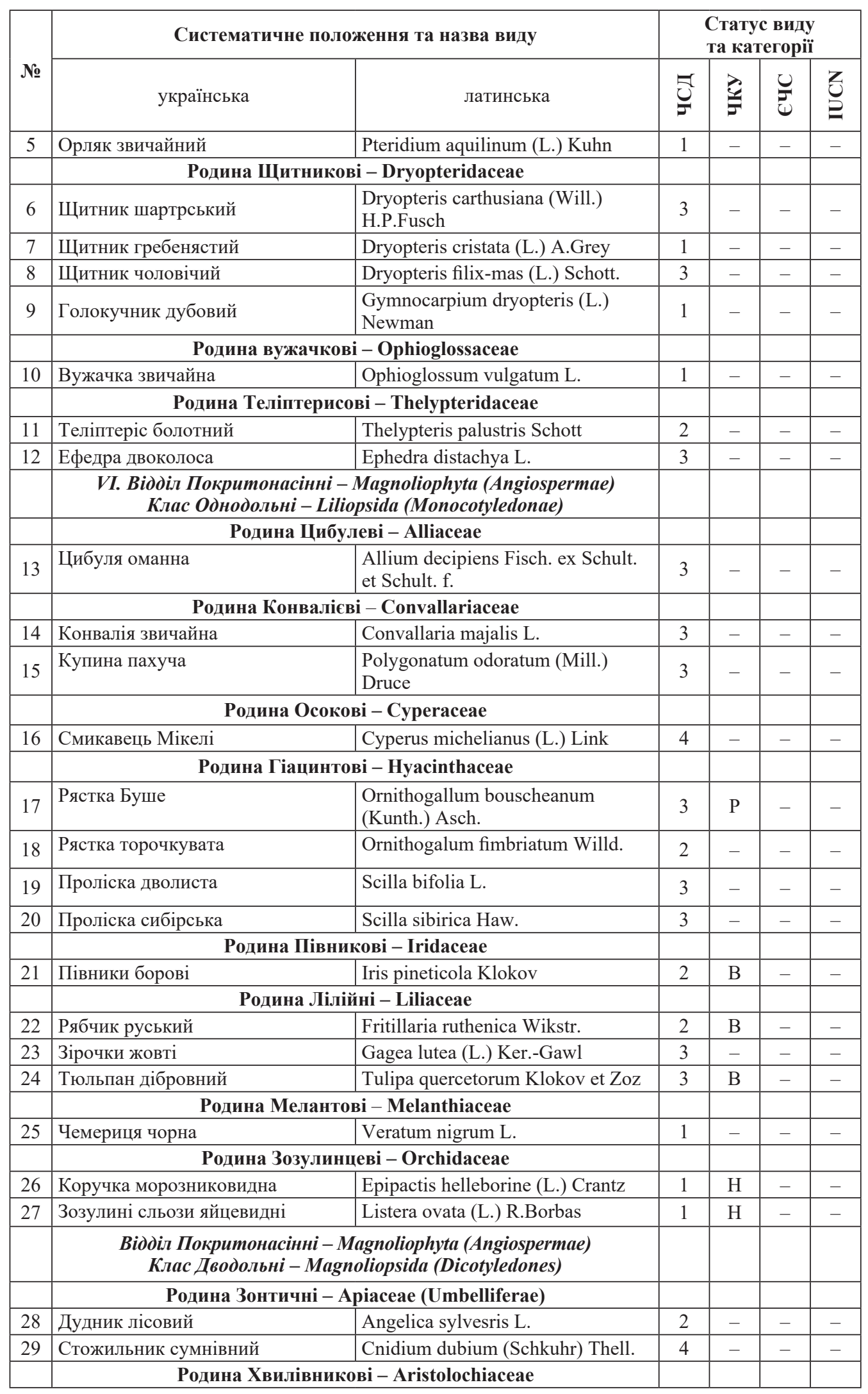


Закінчення табл. 1

\begin{tabular}{|c|c|c|c|c|c|c|}
\hline \multirow[b]{2}{*}{ № } & \multicolumn{2}{|c|}{ Систематичне положення та назва виду } & \multicolumn{4}{|c|}{$\begin{array}{l}\text { Статус виду } \\
\text { та категорії }\end{array}$} \\
\hline & українська & латинська & 气̂ & 光 & $\stackrel{己}{\mho}$ & Z \\
\hline 30 & Копитняк європейський & Asarum europaeum L. & 3 & - & - & - \\
\hline \multicolumn{7}{|c|}{ Родина Ластівневі - Asclepiadaceae } \\
\hline 31 & Ластовень руський & $\begin{array}{l}\text { Vincetoxicum rossicum (Kleopov) } \\
\text { Barb. }\end{array}$ & 1 & - & - & $\mathrm{R}$ \\
\hline \multicolumn{7}{|c|}{ Родина Айстрові - Asteraceae } \\
\hline 32 & Полин понтійський & Artemisia pontica L. & 4 & - & - & - \\
\hline 33 & Ахірофорус плямистий & Hypochaeris maculata L. & 4 & - & - & - \\
\hline 34 & Козельці українські & Tragopogon ucrainicus Artemcz. & 4 & - & $\mathrm{R}$ & - \\
\hline \multicolumn{7}{|c|}{ Родина Барбарисові - Berberidaceae } \\
\hline 35 & Барбарис звичайний & Berberis vugaris L. & 3 & - & - & - \\
\hline \multicolumn{7}{|c|}{ Родина Березові - Родина Betulaceae } \\
\hline 36 & Вільха клейка & Alnus glutinosa (L.) Gaertn. & 3 & - & - & - \\
\hline \multicolumn{7}{|c|}{ Родина Дзвоникові - Родина Campanulaceae } \\
\hline 37 & Аденофора лілієлиста & $\begin{array}{l}\text { Adenophora lilifolia (L.) Ledeb. ex } \\
\text { A. DC. }\end{array}$ & 1 & - & - & - \\
\hline 38 & Дзвоники скупчені & Campanula glomerata L. & 3 & - & - & - \\
\hline 39 & Дзвоники персиколисті & Campanula persicifolia L. & 2 & - & - & - \\
\hline 40 & Дзвоники круглолисті & Campanula rotundifolia L. & 1 & - & - & - \\
\hline 41 & Дзвоники крапиволисті & Campanula trachelium L. & 3 & - & - & - \\
\hline \multicolumn{7}{|c|}{ Родина Гвоздичні - Caryophyllaceae } \\
\hline 42 & Гвоздика Борбаша & Dianthus borbasii Vandas & 1 & - & - & - \\
\hline \multicolumn{7}{|c|}{ Родина Товстолисті - Crassulaceae } \\
\hline 43 & Молодило руське & $\begin{array}{l}\text { Sempervivum ruthenicum } \\
\text { Schnittsp. et C.B. Lehm. }\end{array}$ & 3 & - & - & - \\
\hline & \multicolumn{2}{|c|}{ Родина Губоцвітні - Lamiaceae } & & & - & - \\
\hline 44 & Буквиця лікарська & Betonica officinalis L. & 3 & - & - & - \\
\hline \multirow[t]{2}{*}{45} & Шоломниця висока & Scutellaria altissima L. & 3 & - & - & - \\
\hline & \multicolumn{2}{|c|}{ Родина Онагрові - Onagraceae } & & & - & - \\
\hline 46 & Хамерій вузьколистий & $\begin{array}{l}\text { Chamaerion angustifolium (L.) } \\
\text { Holub }\end{array}$ & 3 & - & - & - \\
\hline \multirow[t]{2}{*}{47} & Зніт гірський & Epilobium montanum L. & 2 & - & - & - \\
\hline & \multicolumn{2}{|c|}{ Родина Грушанкові - Родина Pyrolaceae } & & & & \\
\hline 48 & Грушанка круглолиста & Pyrola rotundifolia L. & 1 & - & - & - \\
\hline \multicolumn{7}{|c|}{ Родина Жовтецеві - Ranunculaceae } \\
\hline 49 & Анемона жовтецева & Anemone ranunculoides L. & 3 & - & - & - \\
\hline \multicolumn{7}{|c|}{ Родина Вербові - Salicaceae } \\
\hline 50 & Верба козяча & Salix caprea L. & 3 & - & - & - \\
\hline \multicolumn{7}{|c|}{ Родина Ранникові - Scrophulariaceae } \\
\hline 51 & Перестріч гребінчастий & Melampyrum cristatum L. & 3 & - & - & - \\
\hline 52 & Вероніка щиткова & Veronica scutellata L. & 2 & - & - & - \\
\hline \multicolumn{7}{|c|}{ Родина Валеріанові - Valerianaceae } \\
\hline 53 & Валеріана бульбиста & Valeriana tuberosa L. & 3 & - & - & - \\
\hline
\end{tabular}

Примітка: ЧСД - Червоний список Дніпропетровської області (з категоріями рідкості), ЧКУ - Червона книга України (Н - неоцінений, В - вразливий, $\mathrm{P}$ - рідкісний), СЧС Європейський червоний список, IUCN - Світовий червоний список.

Висновки. Аналіз раритетної фракції флори території лівобережжя долини р. Оріль показав, що у лісових екосистемах цієї території зростає 53 види рідкіс- 
них та зникаючих рослин: 1 вид - із Світового червоного списку; 1 вид із Європейського червоного списку; 6 видів - із Червоної книги України, 53 види - iз Червонного списку Дніпропетровської області.

Доля рідкісних та зникаючих видів лісових екосистем по відношенню до всієї раритетної флори (140 видів) дослідженої території складає 30 \%, що свідчить про созологічну цінність лісових екосистем долинно-терасових ландшафтів Степової зони України, які, незважаючи на багаторічну антропогенну трансформацію, зберегли достатній рівень фіторізноманіття.

У процесі досліджень флори долини р. Оріль виявлено низку нових місцезнаходжень рідкісних для області та регіону видів.

\section{Бібліографічні посилання}

1. Барановський Б. О., Манюк В. В., Іванько І. А., Кармизова Л.О. Аналіз флори національного природного парку «Орільський». Дніпропетровськ: Вид-во «Ліра». 2017. $320 \mathrm{c}$.

2. Бельгард А. Л. Лесная растительность юго-востока УССР. Киев: Изд. КГУ. 1950. $227 \mathrm{c}$.

3. Бельгард О. Л., Кириченко Т. Ф. До типології заплавних лісів Середнього Дніпра. Збір. робіт біол. факультету ДДУ. 1938. Вип. 2. Т. ІХ. С. 192-141.

4. Бельгард А. Л., Кириченко Т. Ф. Леса долины р. Орели. Сб. работ биофака ДГУ. Днепропетровск, 1940. Вып. 3.

5. Визначник рослин Украӥни. Київ: Урожай, 1965. 876 с.

6. Гамуля Ю. Г. Эколого-флористические особенности травяного покрова галофитных дубрав долины реки Орель Екологія та ноосферологія. 1999. Вип. 6. № 1-2. C. $70-74$.

7. Гамуля Ю. Г. Біогеоценологічна характеристика галофітних дібров Степового Придніпров'я, їх охорона, поновлення і раціональне використання: автореф. дис. на здобуття наук. ст. канд. біол. наук. Дніпропетровськ. 2001. 26 с.

8. Манюк В. В. До флористичного і фітоценотичного різноманіття долини р. Дніпра на ділянці між старим і новим руслом р. Орелі Актуальні питання ботаніки та екології. Матеріали конференції молодих вчених-ботаніків України (13-16 вересня 2000 р., Чернігів, Седнів). Київ, 2000. С. 49-50.

9. Манюк $\boldsymbol{B}$. $\boldsymbol{B}$. Шульгівський природний комплекс як ключова ділянка національного природного парку «Орільський». Охорона довкілля: зб. наук. статей XI Всеукраӥнських наукових Талї̈вських читань. Харків: ХНУ ім. В. Н. Каразіна, 2015. С. 205-211.

10. Определитель высших растений Украины. Киев: Наука. думка, 1987. 548 с.

11. Tapacoв B. В. Флора Дніпропетровської та Запорізької областей. Дніпропетровськ: Вид-во ДНУ та Ліра. 2012. 296 с.

12. Червона книга Украӥни. Рослинний світ. За ред. Я. П. Дідуха. Київ: Глобалконсалтинг, 2009. 912 с.

13. Червоний список видів рослин і тварин Дніпропетровської області. Затверджений рішенням обл. ради депутатів 27.12.2011р. № 219-10/VI. 27 с.

14. Mosyakin S. L., Fedoronchuk M. M. Vascular plants of Ukraine. Nomenclatural checklist. Київ: 1999. 346 c.

15. Multifunctional floodplain management and biodiversity effects: a knowledge synthesis for six European countries. S. Schindler, F. H. O’Neill, M. Biró, C. Damm, V. Gasso, R. Kanka, T. Sluis, A. Krug, S. G. Lauwaars, Z. Sebesvari, M. Pusch, B. Baranovski, T. Ehlert, B. Neukirchen, J. R. Martin, K. Euller, V. Mauerhofer, T. Wrbka. Biodivers conservi (2016) 25:1349-1382.

Надійшла до редколегії 23.05.2016 p. 